KATARZYNA ANNA MICH

Uniwersytet Kardynała Stefana Wyszyńskiego w Warszawie

\title{
Wolontariat misyjny na przykładzie doświadczeń misyjnych Akademickiego Koła Misjologicznego im. dr Wandy Błeńskiej w Poznaniu - turystyka religijna czy świadectwo wiary?
}

„Oto ja poślij mnie!” - można zauważyć, że zapał misyjny do dzielenia się doświadczeniem Miłości Boga charakteryzuje nie tylko wykwalifikowanych misjonarzy i misjonarki, ale cechuje on także wielu młodych, którzy coraz częściej i liczniej udają się na krótkie wolontariaty misyjne w różne rejony świata, by poprzez swoją pracę i modlitwę, poświęcając swój wolny czas, pomagać misjonarzom w ich trudnej pracy (Gądecki, Homilia w trakcie IV Kongresu Misyjnego).

Wolontariat misyjny nie jest wyjazdem na misje, ale doświadczeniem życia na misji, możliwością dotknięcia przez krótki czas innej kultury, zwyczajów i tradycji, a także wymiany doświadczeń i przede wszystkim czasem dzielenia się wiarą i religijnością ze spotkanymi ludźmi. To przede wszystkim ofiarowanie swojego czasu Panu Bogu i drugiemu człowiekowi.

Jednak bardzo często można się spotkać z zarzutem, że wolontariat misyjny to nic innego niż turystyka religijna, a nie doświadczenie wiary. Wśród zarzutów wobec wyjazdów na wolontariat misyjny podnosi się także argument, że przez krótki czas, jakim jest na przykład miesiąc, młodzi ludzie nic sensownego nie są w stanie zrobić i będą stanowić jedynie problem dla misjonarzy, którzy będą musieli przez ten czas się nimi zająć. Pojawia się też bardzo często argument finansowy, że pieniądze przeznaczane na wyjazdy na wolontariat misyjny lepiej byłoby przesłać do danego kraju, a pracujący tam misjonarz będzie najlepiej wiedział, w jaki sposób je wykorzystać.

Czy krótkoterminowe wolontariaty misyjne są w ogóle potrzebne? Czy jest sens ich organizowania, czy są jedynie stratą czasu i pieniędzy, a przyjazd młodych ludzi workiem problemów dla misjonarza? Przykład doświadczeń misyjnych Akademickiego Koła Misjologicznego im. dr Wandy Błeńskiej 
pokazuje, że doświadczenie misyjne jest dla młodych ludzi czasem spotkania z Bogiem i z drugim człowiekiem, poznawania swojego powołania, ale także poszukiwaniem swojego miejsca w Kościele; a dla misjonarzy pomocą w realizowaniu ich misji, ale i nawiązaniem współpracy ze świeckimi w Kościele i dla Kościoła (Prośmy o pokój dla Jeruzalem).

\section{Powołanie świeckich do apostolstwa}

Kościół ze swojej natury jest misyjny i jego posłannictwo do misji stanowi jego tożsamość Kościoła. Każdy chrześcijanin jest powołany i posłany do świadczenia o Jezusie i królestwie Bożym, które On głosił i realizował ( $A d$ gentes 1-2).

Na mocy chrztu wszyscy chrześcijanie są przez Pana wezwani do rzeczywistego apostolstwa, ponieważ powołanie chrześcijańskie jest z natury swojej również powołaniem do głoszenia (Apostolicum actuositatem, 2). Podstawą tego powołania jest łaska chrztu: chrześcijanie, wszczepieni przez chrzest w Chrystusa, stają się uczestnikami Jego potrójnego urzędu: kapłańskiego, prorockiego i królewskiego. Bierzmowanie utwierdza ich mocą Ducha Świętego, a Eucharystia wpaja w nich i podsyca ową miłość do Boga i ludzi, która jest duszą całego apostolstwa (Amaladoos).

Papież Franciszek uczy, że każdy, kto przyjmuje chrzest, staje się uczniemmisjonarzem. Każdy, niezależnie od swojej funkcji w Kościele czy wykształcenia w wierze, jest misjonarzem. Myślenie, że misje mogą prowadzić jedynie wykwalifikowani misjonarze, podczas gdy reszta Ludu Bożego miałaby się jedynie modlić za owocność głoszenia słowa Bożego i wspierać je materialnie, jest wysoko niestosowne. Każdy, kto doświadczył rzeczywiście miłości i czułości Boga, powinien niezwłocznie zacząć głosić orędzie o Bożej Miłości (Evangelii gaudium, 120).

Jak zauważa abp Stanisław Gądecki (Radość przekazywania wiary),

Kto jest ochrzczony i żyje chrztem, ten jest misjonarzem. [...] Misjonowanie jest drogą do dojrzewania pojedynczego człowieka. Żaden katolik, który wchodzi w tę tożsamość chrzcielną, wchodzi w chrzest, nie potrzebuje się obawiać tego, że jest zbyt nierozgarnięty albo za mało wykształcony w teologii, albo w ogóle wykształcony.

Kościół potrzebuje dzisiaj ludzi świeckich, ludzi dojrzałych, którzy odgrywając rolę uczniów i świadków Chrystusa, będą budowali wspólnoty chrześcijańskie i przeobrażali świat $\mathrm{w}$ duchu wartości ewangelicznych (Jan Paweł II, Orędzie na Niedzielę Misyjną 1987). Odpowiedzialność za głoszenie 
Chrystusa spoczywa na wszystkich członkach Kościoła i choć każdy z nich jest równocześnie podmiotem i przedmiotem misji, to zasady i sposoby tego uczestnictwa są zróżnicowane w zależności od zajmowanego miejsca i funkcji pełnionej wewnątrz Kościoła oraz od rodzaju sprawowanej posługi i osobistych charyzmatów.

Posługa świeckich w działalności misyjnej Kościoła ma ogromne znaczenie, Ewangelia nie może bowiem zapuścić swoich korzeni bez ich udziału, zwłaszcza że działając i wywodząc się z określonego narodu i środowiska, swoim świadectwem kształtują i tworzą dojrzały, chrześcijański laikat. Paweł VI w Evangelii nuntiandi podkreśla znaczącą rolę rodziny w przekazywaniu wiary, uznając tę podstawową komórkę społeczną za element kształtujący rysy Kościoła powszechnego.

Jednakże apostolstwo świeckich musi przebiegać - oczywiście z zachowaniem zdrowego pluralizmu - w autentycznym zjednoczeniu z pasterzami Kościoła i być udziałem w misji ewangelizacyjnej całego Ludu Bożego (Jan Paweł II, Ewangelizacja a instytuty świeckie).

Świeccy powinni zostać odpowiednio przygotowani do różnych zadań powierzonych im przez Kościół, by mogli je wykonać świadomie, gorliwie i starannie. Wypracowują oni jedyną i niepowtarzalną duchowość ewangeliczną dostosowaną do warunków i okoliczności, w jakich spełniają swój zawód. Wierni świeccy na mocy sakramentów chrztu i bierzmowania partycypują w misji pasterskiej Kościoła. Laikat w pracy misyjnej w znacznej mierze staje się pomocny w głoszeniu orędzia zbawienia poprzez czynny udział w działalności duszpasterskiej (Szymański).

\section{Wolontariat misyjny jako forma działalności misyjnej}

Powołanie do apostolstwa ludzi świeckich, zwłaszcza młodych, może się realizować poprzez wolontariat odbyty w prowadzonej przez misjonarzy placówce. Jego celem jest pomoc w ich codziennych obowiązkach.

Wolontariat ten jest formą zaangażowania młodych ludzi, którzy chcą zrobić coś dobrego w miejscach, gdzie są potrzebni. Poprzez poświęcenie swojego czasu oraz funduszy młodzi ludzie wspierają misjonarzy. Wolontariat misyjny oznacza ściśle ukierunkowaną działalność, tam gdzie prowadzone są misje. Może być ona krótkoterminowa (od kilku tygodni do sześciu miesięcy) albo długoterminowa (od sześciu miesięcy do dwóch lat) (Jabłoński).

W Polsce organizacja wolontariatów misyjnych jest prowadzona głównie przez zakony misyjne, jak: Salezjański Wolontariat Misyjny Młodzi Światu, Werbistowski Wolontariat Misyjny Apollos, Wolontariat Misyjny Salvator, Wolontariat Misyjny Sióstr Białych, Pallotyńska Fundacja Misyjna „Salvat- 
ti”, Oblacki Wolontariat Misyjny „Niniwa”, ale także przez organizacje, jak: Fundacja Pomocy Humanitarnej „Redemptoris Missio”, Fidesco, wspólnoty religijne, jak Diakonia Misyjna Ruchu Światło-Życie, zrzeszenia studentów, jak Akademickie Koło Misjologiczne, czy też przez parafie bądź indywidualne projekty (Komisja Episkopatu Polski ds. Misji).

Obecnie jest wiele możliwości wyjazdu na wolontariat misyjny, przez co $\mathrm{z}$ roku na rok coraz więcej młodych ludzi angażuje się w taką formę spędzania wolnego czasu, zwłaszcza w okresie wakacyjnym. Najczęściej wyjeżdżają studenci i absolwenci studiów (Jabłoński).

Wolontariat misyjny ma różne formy finansowania, teraz można uzyskać fundusze z Unii Europejskiej bądź Ministerstwa Spraw Zagranicznych. Bardzo często organizacje wysyłające młodych ludzi pomagają w zebraniu funduszy na wyjazd bądź je współfinansują. Do źródeł finansowania należą także: zbiórki w parafiach, rozprowadzanie cegiełek misyjnych czy też fundusze własne. Wolontariusz jest odpowiedzialny za sfinansowanie wyjazdu i pobytu na placówce misyjnej, aby nie stanowił obciążenia materialnego dla misjonarza, do którego się udaje.

Coraz więcej polskich misjonarzy zauważa potrzebę współpracy ze świeckimi, otwiera się na wolontariuszy misyjnych. Misjonarze dostrzegają w młodych ludziach ich zapał do głoszenia świadectwa wiary w Jezusa Chrystusa, ale także widzą nowe możliwości współpracy poprzez zapraszanie ich w celu realizacji projektów.

W Polsce długo nie było możliwości wysyłania młodych na placówki misyjne. Gdy na Zachodzie rozwijała się idea wolontariatów misyjnych, zwłaszcza w Hiszpanii, we Włoszech czy w Niemczech, w Polsce panował system komunistyczny, który utrudniał wyjazdy zagraniczne. Po upadku systemu komunistycznego rozwój tej formy zaangażowania świeckich był również utrudniony, przede wszystkim z powodów finansowych.

Dzisiaj w Polsce możemy zaobserwować niesamowity rozwój wolontariatów misyjnych. $\mathrm{Z}$ roku na krok przybywa wolontariuszy udających się na placówki misyjne i realizowanych projektów misyjnych (bp Mazur: Czas na świecki wolontariat misyjny).

Funkcjonowanie wolontariatu misyjnego w Polsce opiera się w głównej mierze na ustawie o działalności pożytku i o wolontariacie z dnia 24 kwietnia 2003 r. (Dz.U. z dnia 29 maja 2003 r.), dotychczas bowiem Komisja Konferencji Episkopatu Polski ds. Misji nie opracowała żadnego dokumentu regulującego kwestię wolontariatów misyjnych.

Można stwierdzić, że owocem IV Kongresu Misyjnego, który odbył się w Polsce w 2015 r., jest zmiana postrzegania tej formy zaangażowania młodych ludzi w dzieło misyjne Kościoła w Polsce. Obecnie Komisja Konferencji Episkopatu Polski ds. Misji prowadzi prace nad znormalizowaniem kwe- 
stii zaangażowania świeckich w misje, w tym wolontariuszy misyjnych oraz świeckich misjonarzy. W czerwcu 2017 r. na Uniwersytecie Kardynała Stefana Wyszyńskiego planowane jest sympozjum poświęcone świeckim na misjach (bp Mazur: Czas na świecki wolontariat misyjny).

Pomimo zauważalnej niechęci do wolontariatów misyjnych w Polsce ta forma zaangażowania rozwija się bardzo dynamicznie. Pokazuje to przykład archidiecezji poznańskiej, gdzie arcybiskup Stanisław Gądecki od 2007 r. posyła młodych ludzi chętnych do takiej służby w Kościele. Od 2011 r. odbywa się to w trakcie uroczystych I Nieszporów ku czci świętych apostołów Piotra i Pawła, patronów tej archidiecezji (wyjątkiem był rok 2015, kiedy młodzi zostali posłani w trakcie Mszy Świętej kończącej IV Kongres Misyjny w farze poznańskiej, transmitowanej przez TV Polonia). Arcybiskup Stanisław Gądecki pokazuje w ten sposób, że taka forma zaangażowania młodych ludzi w dzieło misyjne Kościoła jest potrzebna i że należy wspierać młodych modlitwą i błogosławieństwem, bierze także za nich odpowiedzialność, bo nie jadą oni na wolontariat misyjny jako zwykli wolontariusze, lecz posłani przez Kościół świadkowie Chrystusa, wolontariusze misyjni. Zaangażowanie arcybiskupa Stanisława Gądeckiego nie kończy się jedynie na posłaniu młodych i wręczeniu im krzyża misyjnego, ale obejmuje także rozmowę z nimi w trakcie trwania wolontariatu czy na wspólnym spotkaniu po powrocie do Polski.

\section{Doświadczenia misyjne Akademickiego Koła Misjologicznego}

W archidiecezji poznańskiej jedną z organizacji, która daje możliwość wyjazdu na wolontariat misyjny, jest Akademickie Koło Misjologiczne im. dr Wandy Błeńskiej (AKM), które działa na Uniwersytecie im. Adama Mickiewicza w Poznaniu, czyli organizacja naukowa zrzeszająca studentów wszystkich poznańskich uczelni. Koło ma swoją siedzibę na Wydziale Teologicznym UAM.

\section{III.1. Działalność Akademickiego Koła Misjologicznego}

Koło sięga w swojej tradycji do założonego w roku 1927 r. Akademickiego Koła Misyjnego, które było pierwszym akademickim kołem misyjnym w Polsce (Stułkowski 110). Wśród pierwszych członków tego Koła były wybitne i zasłużone osoby dla poznańskiej i polskiej historii, m.in. prof. Gerard Labuda i wybitna poznańska misjonarka z Ugandy - dr Wanda Błeńska. Działalność Koła została przerwana z powodu wybuchu II wojny światowej. Dzięki inicjatywie Joanny Muszyńskiej oraz zaangażowaniu Anny Świątek, Iwony 
Markuszewskiej i Joanny Krawiec, a także wsparciu ks. dr. Ambrożego Andrzejaka oraz sióstr ze Zgromadzenia Sióstr Misjonarek św. Piotra Klawera Koło zostało reaktywowane w 2002 r. Pierwszym opiekunem jego naukowym został o. Wojciech Kluj OMI. Po nim obowiązki te pełnił ks. Waldemar Babicz, a od 2006 r. opiekunem jest ks. Szymon Stułkowski (Prośmy o pokój dla Jeruzalem, s. 8). Od listopada 2015 r. Koło nosi imię swojego honorowego członka dr Wandy Błeńskiej. Przyjęcie tego patronatu podkreśla łączność pomiędzy dawną i dzisiejszą działalnością.

Głównym zadaniem Koła jest przede wspieranie misji Kościoła katolickiego, co realizowane jest poprzez animację misyjną, popularyzację wiedzy misjologicznej, organizowanie seminariów i zjazdów naukowych na temat misji oraz modlitewne i materialne wsparcie misjonarek i misjonarzy rozsianych na całym świecie (Stułkowski, 110-111).

Zadanie wspierania misji Koło realizuje poprzez trzy filary:

- Modlitwę, która jest fundamentem każdego ludzkiego działania, dlatego w centrum comiesięcznych spotkań AKM znajduje się Msza Święta. W Kole podejmowany jest także Żywy Różaniec Misyjny, obecnie istnieje osiem róż różańcowych (Stułkowski, 111-112).

- Formację naukową i duchową. Na spotkaniach Koła goszczą misjonarze, zarówno księża, siostry zakonne, jak i świeccy, którzy dzielą się swoimi doświadczeniami, radościami i troskami pracy misyjnej oraz opowiadają o warunkach życia panujących w krajach, gdzie pracują. W Kole bardzo ważny akcent kładzie się na studiowanie dokumentów Kościoła dotyczących misji, zwłaszcza na encyklikę Jana Pawła II Redemptoris missio, adhortację Pawła VI Evangelii nuntiandi (Prośmy o pokój dla Jeruzalem, s. 11). Obecnie studenci czytają i rozważają dokument papieża Franciszka Evangelii gaudium.

Koło bierze również udział w sympozjach i konferencjach naukowych oraz realizuje projekty naukowo-badawcze. W roku 2016 Koło udzieliło wsparcia młodzieży z Boliwii, Etiopii, Wysp Zielonego Przylądku, z Ziemi Świętej na przyjazd do Polski na Światowe Dni Młodzieży w Krakowie.

- Animację misyjną, która jest dzieleniem się zapałem misyjnym, przekazywaniem wiedzy nt. działalności misyjnej Kościoła oraz rozbudzaniem świadomości odpowiedzialności każdego ochrzczonego za głoszenie Ewangelii (Prośmy o pokój dla Jeruzalem, s. 12).

Szczegółowe informacje o działalności Koła można uzyskać w corocznych sprawozdaniach z działań Koła publikowanych w „Annales Missiologici Posnanienses" (np. Mich 2014, 2015a i 2015b). 


\section{III.2. Doświadczenia misyjne}

Jedną z form działalności Akademickiego Koła Misjologicznego jest organizowanie wyjazdów na wolontariat misyjny, który w Kole nazywa się doświadczeniem misyjnym. Według opiekuna Koła ks. Szymona Stułkowskiego: „Chodzi o to, by sprawdzić się w konkretnym działaniu na terenie misyjnym, innym kulturowo od tego, w którym żyje się na co dzień" (Stułkowski, 118).

Nie jest to wyjazd na misje, ale doświadczenie misji, możliwość dotknięcia przez krótki czas prawdziwej pracy misyjnej, jak również innej kultury, zwyczajów i tradycji, a także wymiany doświadczeń i przede wszystkim dzielenia się wiarą i religijnością. W trakcie tych doświadczeń narodziły się nowe przyjaźnie, wielu miało możliwość zastanowienia się nad swoim powołaniem (Tobolski). Dotychczas udało się zrealizować kilka takich projektów.

Pierwszym doświadczeniem misyjnym Akademickiego Koła Misjologicznego był wyjazd w 2007 r. grupy młodych ludzi do Kazachstanu, by współorganizować spotkanie młodych z Azji Środkowej. Rok później odbyło się doświadczenie misyjne w Republice Zielonego Przylądka, gdzie członkowie Koła prowadzili rekolekcje dla młodzieży - Campo Escola (Czas spotkania). Dzięki nawiązanym tam znajomościom oraz przyjaźniom Koło zaprosiło animatorów duszpasterstwa młodzieży z Cabo Verde do Polski, a w 2011 r. ponownie członkowie Koła prowadzili na Cabo Verde rekolekcje dla młodzieży oraz udało się zorganizować kurs fizjoterapii.

Od 2010 r., AKM co roku organizuje doświadczenia misyjne w Jerozolimie w „Domu Pokoju”, czyli w prowadzonym przez polskie elżbietanki sierocińcu dla dzieci. Także w 2016 r. grupa studentów pojechała do Jerozolimy. Od 2015 r. w ciągu roku szkolnego możliwe jest również uczestnictwo w doświadczeniu w Jerozolimie i w Betlejem, które polega na pomocy w opiece nad dziećmi.

W 2014 r. grupa studentów udała się do Kazachstanu, aby w parafii w Kellerowce zająć się remontem ochronki i pomocą w pracy z dziećmi i młodzieżą, a dwie osoby z Koła wzięły udział w doświadczeniach misyjnych zorganizowanych przez inne wspólnoty w Kamieńcu Podolskim na Ukrainie i w Ugandzie.

W 2015 r. udało się zorganizować doświadczenie misyjne w Etiopii, podczas którego dwie studentki pomagały w szpitalu prowadzonym przez siostry miłosierdzia.

a) Przygotowanie do wyjazdu

Członkowie Koła, którzy wykazują duże zaangażowanie w podejmowane przez Koło inicjatywy, uczestniczą w spotkaniach Koła, mają możliwość 
zgłoszenia swojej kandydatury na wyjazd na doświadczenie misyjne. Zarząd Koła wraz z opiekunem wybiera spośród zgłoszonych osób uczestników doświadczenia misyjnego, biorąc pod uwagę ich dotychczasowe zaangażowanie, predyspozycje do pracy fizycznej w odmiennych warunkach klimatycznych, umiejętność pracy w grupie oraz osobiste motywacje. Koło nie jest biurem podróży, które wysyła każdego, kto się zgłosi, na wyjazd na wolontariat misyjny (Tobolska).

Po ogłoszeniu listy osób, które będą uczestniczyły w doświadczeniu misyjnym, rozpoczynają się dla nich intensywne przygotowania, które mają na celu zintegrowanie grupy, uświadomienie sobie motywacji do wyjazdu, poznanie kultury, historii oraz problemów miejsca, gdzie odbędzie się doświadczenie misyjne. Nacisk kładziony jest przede wszystkim na formację duchową (Prośmy o Pokój dla Jeruzalem, 18).

O zebranie funduszy na wyjazd troszczą się uczestnicy doświadczenia. Większość pieniędzy, poza wkładem własnym, jest otrzymywana od ofiarodawców i dobroczyńców w trakcie animacji misyjnych w parafiach przede wszystkim w archidiecezji poznańskiej, dzięki rozprowadzaniu cegiełek misyjnych wykonanych samodzielnie lub przywiezionych z krajów misyjnych. Inną formą uzyskiwania funduszy jest akcja „Palemki” - studenci przygotowują bukiety palm, które rozprowadzane są w Niedzielę Palmową (Prośmy o Pokój dla Jeruzalem, 18-19).

\section{b) Postanie misyjne}

Od pierwszego doświadczenia misyjnego w Kazachstanie w 2007 r. ksiądz arcybiskup Stanisław Gądecki, metropolita poznański patronuje wyjazdom na wolontariat misyjny Akademickiego Koła Misjologicznego i przekazuje krzyże misyjne podczas uroczystego rozesłania, o czym była mowa wcześniej.

Posłanie misyjne jest dla młodych ludzi duchowym wsparciem, daje pewność, że ksiądz arcybiskup wraz z całym Kościołem otacza ich swoją opieką i biorą za nich odpowiedzialność. Jest to nie tylko wspaniałe wyróżnienie oraz docenienie osób udających się na wolontariat misyjny, ale także również wyraz zaufania w stosunku do posyłanych młodych ludzi. Ich zadaniem jest głoszenie świadectwa wiary katolickiej, nie tylko słowem, lecz również czynem, co trzeba czynić roztropnie oraz umiejętnie.

Luiza Nadstazik, uczestniczka doświadczenia misyjnego w Jerozolimie tak wspomina to ważne dla niej wydarzenie:

14 czerwca 2015 roku byłam posłana przez księdza arcybiskupa na doświadczenie misyjne do Jerozolimy. Było to dla mnie bardzo ważne przeżycie, które z radością dzieliłam wraz z rodziną oraz znajomymi. Upewniłam się, że miesiąc pracy w Domu Pokoju na Górze Oliwnej, do którego się przygotowywałam, jest ważny 
w działalności Kościoła i ma głęboki sens. To mój wkład w misyjne dzieło, które choć jest namiastką „prawdziwej” misji, to może wnieść wiele dobrego i ucieszyć innych ludzi, a przez to Najważniejszego - Pana Boga. Posłanie misyjne dało mi jeszcze więcej łask do wypełniania swojego zadania na izraelskiej ziemi. To radosne święto ukazało także piękno i jedność wszystkich misjonarzy.

\section{c) Modlitwa i praca}

Doświadczenie misyjne realizowane przez Akademickie Koło Misjologiczne jest realizowane według starej, benedyktyńskiej zasady Ora et labora (módl się i pracuj).

Modlitwa jest nieodłącznym elementem doświadczenia misyjnego. Uczestnicy w trakcie pobytu modlą się za siebie wzajemnie, każdy modli się za jedną wylosowaną osobę. Bardzo ważne jest rozpoczęcie każdego dnia Mszą Świętą, a zakończenie wspólnymi nieszporami. W trakcie doświadczenia misyjnego nie zapomina się również o adoracji Najświętszego Sakramentu, drodze krzyżowej, różańcu, koronce do miłosierdzia Bożego. Wspólna modlitwa jednoczy młodych ludzi wokół Jezusa Chrystusa i silnie kierunkuje ich na bycie narzędziami miłosierdzia w rękach Pana. Dodaje również sił w trudnych chwilach (Prośmy o Pokój dla Jeruzalem, 56-67).

Celem projektów realizowanych przez Koło jest konkretna pomoc misjonarzom w ich placówkach misyjnych - od prac remontowo-porządkowych, na które misjonarze zwykle nie mają czasu, przez opiekę nad dziećmi czy chorymi w szpitalu, po organizowanie rekolekcji i półkolonii dla dzieci i młodzieży. $\mathrm{W}$ trakcie doświadczenia misyjnego podejmowana jest nie tylko praca fizyczna, ale także duchowa praca nad sobą, nad własnymi wadami, lękami, ograniczeniami (Prośmy o Pokój dla Jeruzalem, 67-87).

\section{d) Świadectwa uczestników doświadczeń misyjnych}

O tym, co doświadczenia misyjne wniosły w życie ich uczestników, najlepiej świadczą ich świadectwa.

Kleryk Jarosław Czyżewski - uczestnik doświadczenia misyjnego w Jerozolimie w 2010 r., obecnie kapłan archidiecezji poznańskiej:

Podczas tamtego pobytu doświadczyłem ducha Nazaretu - życia codziennością na wzór św. Rodziny. To, że mogłem w Ojczyźnie Pana Jezusa - tak jak On - mieszkać, modlić się, pracować, odpoczywać, kochać innych, jest dla mnie czymś niezapomnianym. Zwyczajna i cicha praca, rozważanie słowa Bożego w miejscach, po których chodził Pan Jezus, a szczególnie modlitwa na Golgocie i w Getsemani wywarły duży wpływ na moje życie i powołanie. Wreszcie doświadczenie wspólnoty, którą tam stworzyliśmy. Wspólna modlitwa, wzajemna życzliwość i pomoc, 
głębokie rozmowy i żarty - to wszystko było dla mnie doświadczeniem Kościoła jako wspólnoty. Chwała Panu!

Katarzyna Arciszewska - uczestniczka doświadczenia misyjnego na Cabo Verde w $2011 \mathrm{r}$.

Zarówno pobyt przyjaciół z Wysp Zielonego Przylądka w Polsce, jak i wolontariat misyjny na Wyspach pokazały, jak ważne jest spotkanie z drugim człowiekiem i jak cenne jest doświadczenie prawdziwej wspólnoty. Uświadomiło, jak istotna jest codzienna obecność, jaką wagę ma wzajemne obdarowanie się uśmiechem, tak drobne gesty są przecież małym zaczątkiem wielkich przyjaźni. Wspólne wykonywanie codziennych czynności, w których pozornie nie ma nic nadzwyczajnego, ma szczególną wartość, gdy realizowane jest w grupie. Takie wydarzenia są doskonałą okazją, by dzielić się wiarą, bo przecież wiara umacnia się, gdy jest przekazywana, dlatego tak ważne jest, by każdy człowiek czuł się odpowiedzialny za Kościół, który ze swej natury jest misyjny.

Krystyna Surma - uczestniczka doświadczenia misyjnego w Betlejem w 2015 r.

Widziałyśmy przez to, jak w różnorodny sposób Duch Święty przemawia przez miejsca, sytuacje i ludzi oraz pracuje w nas. Bóg zaprosił nas do Betlejem, Domu Chleba, a Maryja chciała ugościć nas w Nazarecie. Był to czas łaski, codziennie czułyśmy się obdarowane. Łaska za łaską - jak mówiłyśmy czy śpiewałyśmy. Spotkałyśmy Go w Siostrach, w dzieciach, z którymi spędzałyśmy czas, w napotkanych ludziach. Jesteśmy Mu wdzięczne za ten czas Jego szczególnej Miłości i błogosławieństwa. Mające obdarować, a jednak obdarowane.

Anna Tomiak - uczestniczka doświadczenia misyjnego w Jerozolimie w 2014 r.

Każdy dzień był wyjątkowy w swojej normalności. Każdy w ziemskiej ojczyźnie Chrystusa czuł się jak u siebie w domu. Był to miesiąc wspólnej pracy, oparty na codziennej Eucharystii, i modlitwy w ciągu dnia. Chwilą wytchnienia były dla nas wieczorne wyjścia do Bazyliki Grobu Pańskiego czy wspólne pielgrzymowanie po Ziemi Świętej oraz zwiedzanie Jerozolimy. Prawie wszystko budziło nieustanny zachwyt i zdziwienie, ale jednocześnie mieliśmy świadomość, że miejsca święte nie są w niczym ważniejsze od Chleba Eucharystycznego, którym karmiliśmy się każdego dnia.

Wyjazd stał się sposobnością do wzrostu duchowego, ćwiczenia się w cierpliwości i relacjach, a także możliwością nawiązania pięknych przyjaźni. Niech Bóg będzie uwielbiony w swoich pięknych planach wobec nas. 


\section{e) Co po powrocie?}

Doświadczenie misyjne nie kończy się wraz z powrotem do codzienności w Polsce, ale w rzeczywistości dopiero się rozpoczyna. Młodzi ludzie przekazują, zwłaszcza podczas animacji czy spotkań ze swoimi rówieśnikami, świadectwo swojej wiary i miłości do Boga i do drugiego człowieka realizowanej $\mathrm{w}$ dobrowolnie poświęconym czasie, aby czynić dobro i przemieniać szarą codzienność w kolorową, przepełnioną uśmiechem i radością.

\section{Podsumowanie}

Wyjazd młodego człowieka na wolontariat misyjny jest przede wszystkim doświadczeniem wiary, złożeniem świadectwa, czasem kształtowania swojego charakteru i poszukiwania odpowiedzi na pytanie o jego miejsce w Kościele oraz w świecie.

Codzienna praca i modlitwa, często w trudnych warunkach, wymaga od młodego człowieka samozaparcia i całkowitego oddania się służbie Bogu i drugiemu człowiekowi. Młody człowiek staje się narzędziem w rękach Pana. Naturalną rzeczą jest to, że mogą pojawiać się kryzysy. Wówczas ważne jest, żeby misjonarz, który przyjmuje wolontariusza, poświęcił mu chwilę czasu i pokazał, jak ważna jest jego praca dla społeczności, w której się znajduje.

Wolontariat misyjny, czy też doświadczenie misyjne, nie jest turystyką religijną, jeśli ma cztery wymiary: chrystologiczny, eklezjalny, apostolski i personalny.

Na pierwszym miejscu zawsze powinno być oddanie chwały Chrystusowi, uwielbienie Go w sposób całkowity. Nie praca jest najważniejsza, lecz uwielbienie poprzez nią Chrystusa Zbawiciela.

Doświadczenie misyjne odbywa się w Kościele, młodzi ludzie dają siebie Chrystusowi, lecz także Kościołowi lokalnemu i powszechnemu. Działają w Kościele dla Jego rozwoju i dobra. Dokładają swoją cegiełkę, wspierając Go modlitwą i pracą.

Czas wolontariatu misyjnego to czas konkretnej pomocy dla konkretnych ludzi. Młody człowiek daje przede wszystkim cząstkę siebie drugiemu człowiekowi, aby wywołać uśmiech na jego twarzy. Dając wiele z siebie, jeszcze więcej się otrzymuje. Bóg nie zapomina o dobru, które się przekazało, ono wraca do nas jeszcze bardziej pomnożone. Doświadczenie misyjne jest czasem, kiedy dane jest szczególne spotkanie z Panem, z Jego Miłością, która jest nieprzebrana.

Jednak to także czas kształtowania własnej drogi życiowej, zastanowienia się nad swoim powołaniem, pracy nad sobą i swoim charakterem. Bardzo często jest to zaparcie samego siebie, wzięcie na swe barki krzyża i pójście za 
Zbawicielem. Praca czasami jest ponad siły, zmęczenie daje się we znaki, ale „wszystko mogę w tym, który mnie umacnia”. Jeśli uzmysłowi się sobie, że doświadczenie misyjne to nie tylko praca, lecz coś zdecydowanie więcej, to wszystko staje się łatwiejsze.

\title{
VOLUNTEER LAY MISSIONARIES - A WITNESS OF FAITH \\ OR RELIGIOUS TOURISM? AN EXAMPLE OF ACADEMIC MISSIOLOGICAL ASSOCIATION IN POZNAN
}

\begin{abstract}
A B S T R A K T
Every year more and more young people decide to dedicate a considerable amount of time to helping missionaries all over the world. In the city of Poznan the leading association offering such opportunities to the students of various local academic institutions is known as Dr Wanda Błeńska's Academic Missiological Association. The article describes their experiences and underlines the importance of missionary voluntary work of young people as the true witness of their faith.
\end{abstract}

Słowa kluczowe: wolontariat misyjny; AKM; doświadczenie misyjne; świeccy; zaangażowanie misyjne

\section{BIBLIOGRAFIA}

Amaladoos, Michael. „Teologia Misji w świetle dokumentów Magisterium Kościoła od Soboru Watykańskiego II do dnia dzisiejszego.” Dostęp 31 sierpnia 2016. http://www2.ofmconv.pen. net/docs/pl/general/miscon06_india/Teologia\%20Misji\%20w\%20swietle\%20dokumentow\%20 Magisterium $\% 20$ Kosciola $\% 20$ od $\% 20$ Soboru $\% 20$ Watykanskiego $\% 20 \mathrm{II} \% 20 \mathrm{do} \% 20 \mathrm{dnia} \% 20$ dzisiejszego.pdf

Czas spotkania. Doświadczenie misyjne na Wyspach Zielonego Przylądka. Red. Paulina Młynarek, Szymon Stułkowski. Poznań: Sekretariat Misyjny Archidiecezji Poznańskiej oraz Akademickie Koło Misjologiczne, 2009.

Franciszek, „Adhortacja apostolska Evangelii Gaudium - o głoszeniu Ewangelii we współczesnym świecie.” wyd. II poprawione. Kraków: Wydawnictwo WAM, 2013.

Gądecki, Stanisław. „Idźcie więc i nauczajcie wszystkie narody. XI Niedziela Zwykła „B” (Fara Poznańska - 14.06.2015)" [Homilia w trakcie IV Kongresu misyjnego w Polsce]. Dostęp 31 sierpnia 2016. http://www.archpoznan.pl/content/view/3628/109/

Gądecki, Stanisław. „Radość przekazywania Ewangelii”. Dostęp 31 sierpnia 2016. https://www. youtube.com/watch? $\mathrm{v}=\mathrm{j} 3 \mathrm{Dj}$ YGIzbac

Jabłoński, Franciszek. „Wolontariat misyjny.” Misyjne Drogi 5 (2012): 12-13.

Jan Paweł II. „Ewangelizacja a instytuty świeckie: Do II Światowego Kongresu Instytutów Świeckich Rzym, 28 sierpnia 1980. " Dostęp 31 sierpnia 2016. http://www.kuria.lublin.pl/instytuty_swieckie/dokumenty/15.htm, [dostęp: 9.12.2012]. 
Jan Paweł II. „Orędzie na Niedzielę Misyjną 1987: Misyjna posługa laikatu.” Dostęp 31 sierpnia 2016. http://ekai.pl/biblioteka/dokumenty/x301/oredzie-na-niedziele-misyjna/,

Komisja Episkopatu ds. Misji, „Wolontariaty misyjne.” Dostęp 31 sierpnia 2016. http://www.misje. pl/linki-342/wolontariaty-misyjne-348

Mich, Katarzyna A. „Sprawozdanie z działalności Akademickiego Koła Misjologicznego w latach 2012/2013.” Annales Missiologici Posnanienses 19 (2014): 267-269.

Mich, Katarzyna A. „Sprawozdanie z działalności Akademickiego Koła Misjologicznego w latach 2013/2014.” Annales Missiologici Posnanienses 20 (2015a): 253-256.

Mich, Katarzyna A. „Sprawozdanie z działalności Akademickiego Koła Misjologicznego w latach 2014/2015." Annales Missiologici Posnanienses 20 (2015b): 257-260.

Niedziela. „Bp Mazur: Czas na świecki wolontariat misyjny.” 4 lutego 2016. Dostęp 31 sierpnia 2016. http://niedziela.pl/artykul/20556/Bp-Mazur-czas-na-swiecki-wolontariat

Prośmy o pokój dla Jeruzalem. Doświadczenie misyjne „Jerozolima 2010”. Red. Jarosław Czyżewski, Szymon Stułkowski. Poznań: Akademickie Koło Misjologiczne oraz Centrum Misyjne w Poznaniu, 2011.

Sobór Watykański II, „Dekret o działalności Misyjnej Kościoła Ad Gentes Divinitus. Sobór Watykański II Konstytucje, dekrety, deklaracje.. Poznań: Wydawnictwo Pallottinum, 1967: 661-739.

Sobór Watykański II. „Dekret o Apostolstwie Świeckich Apostolicum actuositatem. Sobór Watykański II Konstytucje, dekrety, deklaracje. Poznań: Wydawnictwo Pallottinum, 1967: 563-627.

Stułkowski, Szymon, „Duszpasterstwo studentów na przykładzie Akademickiego Koła Misjologicznego w Poznaniu.” Teologia Praktyczna 10 (2009): 109-123.

Szymański, Dawid. „Uprawnienia misyjne poszczególnych członków Ludu Bożego.” Dostęp 31 sierpnia 2016. http://www.archpoznan.org.pl/serwis/artykuly/2005/1/misja1.pdf

Tobolska, Kamila. „Nie jesteśmy biurem podróży.” Przewodnik Katolicki. Dostęp 31 sierpnia 2016. https://www.przewodnik-katolicki.pl/Archiwum/2014/Przewodnik-Katolicki-27-2014/Wiara-iKosciol/Nie-jestesmy-biurem-podrozy

Tobolski, Błażej. „Wolontariusze z Misją” Przewodnik Katolicki. Dostęp 31 sierpnia 2016. https:// www.przewodnik-katolicki.pl/Archiwum/2014/Przewodnik-Katolicki-27-2014/Wiara-iKosciol/Wolontariusze-Z-misja

Katarzyna Anna Mich - Absolwentka archeologii i teologii na Uniwersytecie im. Adama Mickiewicza w Poznaniu. Doktorantka misjologii w Instytucie Dialogu i Kultury na Uniwersytecie Kardynała Stefana Wyszyńskiego w Warszawie. W latach 2010 do 2016 zaangażowana w prace Akademickiego Koła Misjologicznego w Poznaniu, brała udział w doświadczeniach misyjnych w Jerozolimie w 2011 i 2012 r. oraz w Kamieńcu Podolskim w 2014 r. W latach 2014/2015 prezes Koła. 